\title{
Curriculum Development in the Industrial Revolution Era 4.0
}

\author{
Ahmad kosasih $^{1, \mathrm{a}),}$ Hery Muljono ${ }^{1}$, Syaadiah Arifin ${ }^{1}$ \\ ${ }^{I}$ Department of pascasarjana,Muhammadiyah Prof. DR. Hamka University, Jakarta, 12790, Indonesia \\ a) Corresponding author: kosasih@uhamka.ac.id
}

\begin{abstract}
This research is on curriculum development, the importance of curriculum development in the Industrial Revolution Era 4.0. Previous research has shown that the development of the current curriculum is faced with the demands of society in general to keep up with the development of Technology. The research methodology is a qualitative method and literature study. This research was conducted at SD Muhammadiyah 12 Pamulang Tangerang Selatan. Information is obtained from several informants such as principals and masters. Information collection methods use observation, in-depth interviews, and documentation. Information analysis use the Interactive Analysis Model. The validity of this research information is the level of credibility, transferability, dependency, and affirmability. The elementary School (SD) of Muhammadiyah 12 Pamulang, Banten conducts curriculum development using a technological approach with the implementation of curriculum development consisting of curriculum planning implemented in the creation of annual programs, semester programs, syllabuses, learning implementation plans, and the least completeness criteria namely: (1) the principles and characteristics of syllabus development in SD Muhammadiyah 12 Pamulang Tangerang Selatan is the arrangement of togetherness with general learning or special learning about setting the purpose of character education methods of learning that can develop the curriculum; (2) principles and characteristics of material development at SD Muhammadiyah 12 Pamulang Tangerang Selatan that the materials applied in this school are not only using available school facilities and infrastructure but also the school environment becomes learning objects or materials applied; (3) the principles and characteristics of the lesson plan at SD Muhammadiyah 12 Pamulang Tangerang Selatan.
\end{abstract}

Keywords: Development, Curriculum, and Industrial Revolution 4.0.

\section{INTRODUCTION}

Modern-day developments and rapid population growth are magnifying the flow of school age groups entering the education system. Competition worldwide is getting tougher amid the rapid development of science and technology in the period of Industrial Revolution 4.0. One thing is for sure, that industry 4.0 is coming and we are unlikely to reject or avoid it. These compositions will keep going, no one else can stop them. Therefore the curriculum must always be developed and refined to match the pace of development of science and technology, as well as the society that is building. In the development of the curriculum, SD Muhammadiyah 12 Pamulang Tangerang Selatan not just includes individuals legitimately identified with the universe of instruction, however in it includes numerous individuals, for example, guardians of understudies, just as different components of society who feel keen on schooling.
According to Fisk as cited by Aziz Hussin, there are nine trends or trends related to education 4.0, namely as follows: [1] First, learning at various occasions and places. Understudies will have more occasions to learn at various occasions and places. E-learning encourages open doors for separation learning and independence. Second, individual learning. Understudies will learn with versatile learning hardware with their capacities. This shows that understudies at more elevated levels are tested with more troublesome assignments and questions when, in the wake of passing a specific degree of competency. Understudies who are experiencing issues with the subjects will get the occasion to rehearse more until they arrive at the necessary level. Understudies will be emphatically fortified during their individual learning structures. This can bring about a positive learning experience and will decrease the quantity of understudies who lose certainty about their scholastic capacities. Here, experts will have the option to see obviously which understudies need assistance in which fields. Third, understudies have a decision in deciding how they learn. 
Albeit each subject showed focuses on a similar reason, the path to that objective can change for every understudy.

Similarly, with individually oriented learning experiences, understudies will have the option to alter their learning arrangements with the apparatuses they feel are vital for them. Understudies will learn with various gadgets, projects and methods dependent on their own inclinations. At this level, the blend of up close and personal learning and blended picking up, switching study halls and bringing your own devices structure a significant wording in this change. Four, project-based learning. Today's students should be able to adapt to project-based learning, as well as in terms of work. This suggests that they should learn how to apply their skills in the short term to various situations. Students already have to get acquainted with project-based learning in high school. It's time for organizing, collaboration, and time management skills to be taught to students to then be able to use each student in their next academic career, Five, field experience. Technological advances enable effective learning of certain spaces, giving more space to acquire skills involving student knowledge and face-toface interaction. Thus, the field experience will be developed through courses or activities. Schools will give more occasions to understudies to procure genuine abilities that speak to their work. This proposes educational plan needs to give more space for understudies to learn all the more legitimately through field encounters, for example, temporary jobs, coaching ventures and cooperative undertakings. Six, interpretation of information. The advancement of PC innovation at last assumes control over the errands of manual (numerical) examination, and promptly handles each factual investigation, depicting and breaking down data and foreseeing future patterns. Subsequently, understudies' understanding of this data will be a considerably more significant piece of things to come educational plan. Understudies are needed to be able to apply hypothetical information to numbers, and utilize their aptitudes to make ends dependent on rationale and pattern data. Seven, mixed ratings. Estimating understudies' capacities through regular evaluation procedures, for example, an inquiry and answer will get unessential or inadequate. Appraisals must change, understudies' authentic information can be surveyed during learning pieces, and the use of information can be tried as understudies chip away at their activities in the field. Eight, student engagement. Understudy inclusion in deciding learning materials or educational plan is significant. Understudies' assessments are considered in planning and refreshing the educational program. Their information enables educational plan architects to create contemporary, cutting-edge and high-value curriculums. Finally, tutoring. Mentoring or mentoring students becomes very important to build student learning.
Mentoring is the basis for student success, thus demanding that the master becomes a facilitator who will guide students through their learning compositions. Nine shifts in education trends of 4.0 above become the master's primary responsibility to students. Instructors should assume a part in supporting the progress and don't think of it as a danger to traditional educating. It's an energizing, invigorating test to act, and gigantic. This variation to instructive patterns ensures people and networks to build up a more complete arrangement of capabilities, aptitudes, and information and release their full inventive potential.

To accomplish 21 st century aptitudes, learning examples and best practices should likewise be changed, one of which is through coordinated learning or blended learning. Blended learning is a method of incorporating the utilization of innovation in discovering that empowers suitable learning for every understudy in the study hall. "Mixed learning enables reflection on learning." Blended learning is one of the learning solutions in revolution period 4.0. According to experts, Blended learning is a combination of online-based learning and face-to-face learning in the classroom. It is a combination of physical learning in the classroom and a virtual environment. Definitions show that mixed learning-based learning is a combination of old literacy and new literacy (human literacy, technology literacy and data)[1]

A good quality curriculum is most likely to be achieved as a result of good quality curriculum development processes. Good processes are: Planned and systematic, Inclusive and consultative, Led by curriculum professionals, Cyclical in nature, and Sustainable. [2]

Curriculum development is defined as planned, a purposeful, progressive, and systematic process to create positive improvements in the educational system. Every time there are changes or developments happening around the world, the school curricula are affected.[3], [4]

Curriculum development can be defined as the process of planning, implementing, and evaluating curriculum that ultimately results in a curriculum plan.[5],[6],[7][8]

Education 4.0 is the personalization of thelearning process, where the learner has completeflexibility to be the architect of his or her ownlearning path and has the freedom to aspire for,approach and achieve personal goals by choice.Personalized learning focuses on addressing anindividual's goal by choosing from a variety ofeducational programs, instructional approaches,learning experiences and academic support strate-gies while keeping in mind the learner's distinctneeds, aspirations and interests[9]

In today's worldwide period, curriculum development is a must. Curriculum development is a 
complex composition, and involves all components that are interconnected and supportive between one component and another. The curriculum is dynamic, there must always be developed, in order to keep up with the development and challenges of the times. Curriculum development must be done systematically and targeted, must have a clear vision and mission, want to be carried where national education goes forward with the development of the curriculum. In developing the curriculum, approaches are needed so that the curriculum can be in accordance with the expected educational objectives. What is meant by approach is how to work by implementing the right strategies and methods by following systematic development steps in order to obtain a better curriculum. The approach can be interpreted as a point of decline or a person's point of view towards a particular composition. The term approach refers to the view of a composition whose nature is still very common. Thus, the approach of curriculum development points to a general point of view or point of view about the compositions of curriculum development. The approaches used are:

\section{a. Academic Subject Approach}

In the approach of academic subjects use the field of study or subject as the basis of curriculum organization, such as mathematics, science, history, geography, or IPA, IPS, and so on as is common in the current educational framework in all schools and colleges. The priority in this approach is the mastery of materials and expositions in certain disciplines. Because every science has a certain sound is different from other scientific systematization. The development of the curriculum of academic subjects is done by preestablishing what subjects students should learn, which is necessary to (preparation) the development of disciplines. From this academic subject approach, it is expected that students can master all the knowledge in the curriculum. Because the curriculum puts knowledge first, education is more intellectual. The curriculum of academic subjects does not mean to only emphasize on the material submitted, in its development gradually pay attention to the compositions of the learning that students do. The chosen learning process depends heavily on what is most important in the material[10]

\section{b. Humanistic Approach}

On a humanistic approach centered on students, being student centered, and prioritizing the affective development of students as a prerequisite and as an integral part of the learning process. The priority humanistic approach is a learning experience directed towards the response of children's interests, needs and abilities[11]

\section{c. Technological Approach}

One of the hallmarks of globalization is the rapid flow of information through various technological tools such as telephone, radio, television, teleconference up to satellite, and internet. The presence of technology needs to be taken advantage of by the world of education in an effort to equalize opportunities, improve quality, relevance and efficiency of education. The perspective of technology as a curriculum is emphasized on the effectiveness of method and material programs to achieve a benefit and success. Technology affects the curriculum in two ways: application and theory. Technology applications are a plan for the use of a variety of tools and media, or instruction base stages. As a theory, technology is used in the development and evaluation of curriculum and instructional materials. The first view states that the utilization of technology is more directed at how to teach it, not what is taught. While the second view states that technology is directed at the application of instructional stages[12]

\section{d. Reconstructionism Approach}

This approach is called Social Reconstrution. The social reconstruction curriculum pays great attention to the curriculum's relationship with social and political economic development. Many of the principles of this group are consistent with the highest ideals, for example the issue of the human rights of minorities, confidence in the intellectuals of society in general, and the ability to determine their own destiny according to their desired direction. The teaching of the social reconstruction curriculum is widely implemented in areas that are not yet developed and the economic level is also not high. The implementation of this teaching is directed to improve their living conditions. In accordance with the potential in the community, the school learns these potentials, with the help of fees from the school government trying to develop those potentials. In agricultural areas, for example, schools must develop agricultural fields, while if the area of industry, then that should be developed by the school is the field of industry. So that the curriculum can meet the needs of the people of the area[12]

\section{e. Accountability Approach}

Accountability or accountability of educational institutions about the implementation of their duties to the community, has lately emerged as an important influence In the world of education. However, according to many observers this accountability, education has urged education in the real sense to be a mere exercise[10] 


\section{f. National Development Approach}

This approach contains three elements:[10]

- Civic education

- Education as a tool for national development

- Practical skills education for everyday life

\section{METHOD}

This study uses qualitative research and literature studies. The main source of information in this study is individualized structure customized organization, the rest are additions, such as documents and others. Thus the source of information in this study is in the form of individualized organization customized structure as the main source, while the source of written information, photos and written notes is an additional source of information. The information collection techniques in this study are interviews, observations and documentation.

Data analysis techniques, after all the data has been collected, then the next step is data management and analysis. What is meant by data analysis is the process of systematically finding and compiling data obtained from interviews, field records, and documentation, by organizing data into categories, describing it into units, performing synesths, compiling them into patterns, choosing which is important and will be studied, and making conclusions so that it is easy to understand by himself or others.

Information analysis in this study uses qualitative information, analysis, so in information analysis while in the field researchers used the Spradley model, which is an information analysis technique that is adapted to the stages in the study, are:

1. During the exploration stage with amazing visit question information collection technique, namely first by selecting social situation (place, entertainer, action),

2. Then after entering the field, starting by assigning an informant "key witness" who is an informant, authoritative and trusted can "open the door" to researchers to enter the research object.

3. Then the researcher interviews the informant, and records the results of the interview conducted. After that the researcher's attention to the research object and start to ask descriptive questions, followed by analysis of the results of the interview. Based on the results of the next interview analysis the researchers conducted an area analysis.

4. In the stage of determining focus (done with focused observation) information analysis is carried out using taxonomic analysis.

5. On the choice stage (done by selecting observation) then the researcher asks contrast questions, which are done with components analysis.

6. Results from components analysis, through analysis of themes researchers found cultural themes. Based on these findings, the researchers then wrote a qualitative research report

\section{RESULTS AND DISCUSSION}

In this study, it was found that SD Muhammadiyah 12 Pamulang has a graduate achievement target, called "Five Output Quality". The five Quality Output are:

1. The Quality of Islam and The Islamic State

The quality of Islam and Muhammadiyahan is specified in the ability of graduates to be able to worship, read and memorize the Qur'an and be noble 2. National Quality

The national qualities are specified to the ability of graduates in leadership, as well as the ability to appreciate the art and culture of the nation, as a form of love of the homeland. One of its activities is the programmatic Hizbul Wathan scouting movement from grade I - VI.

3. Academic Quality

Academic quality is specified for the average minimum graduate grade in 8.0

4. Language Quality

The quality of language is specific to the ability of graduates to speak Indonesian and foreign languages, namely English and Arabic. To support the quality of language, especially in English, SD Muhammadiyah 12 Setiabudi Pamulang implemented Bilingual Based Progressive Class from grade III to grade VI. Grade III VI is made by a progressive learning group.

5. Quality Technology Skills

The quality of technology skills is specific to the ability of graduates to mastery of operating computers and other information technologies. One of its activities is the development of robotic technology.

Other research findings mentioned here to achieve the target of becoming a superior school so as to gain public trust, especially print output that is ready to answer global challenges are:

1. Understand the vision and mission of the school that has been set.

2. Implement school-based management.

3. Establish harmonious partnerships with institutions outside SD Muhammadiyah 12 Setiabudi Pamulang. Kindergarten and PAUD, Education Office from UPT for Central, Muhammadiyah Leadership from Branch to Central and other competent institutions.

4. Conduct a programmatic appeal study to more advanced schools to add insight and information 
on the progress of the world of education outside of SD Muhammadiyah 12 Setiabudi Pamulang.

5. Programmatic teacher coaching through supervision, training, seminars and others.

6. Create a harmonious working atmosphere in the school environment.

7. Hold an open house every year.

8. Conduct a review of curriculum targets every year.

9. Maximize the implementation of school programs managed by each field. Namely Curriculum, Human Resources and Development, Student and Public Relations and Ismubaris Field (Al Islam, Arabic and English).

10. Conduct regular evaluation and coordination (once a month) and end of the activity (incidental).

11. Conduct regular evaluation and coordination (once a month) and end of the activity (incidental).

\section{CONCLUSIONS}

SD Muhammadiyah 12 Pamulang, Banten conducts curriculum development using a technological approach with the implementation of curriculum development consisting of curriculum planning implemented in the creation of annual programs, semester programs, syllabuses, learning implementation plans, and minimum completeness criteria namely: (1) principles and characteristics of syllabus development in SD Muhammadiyah 12 Pamulang Tangerang Selatan is the arrangement of togetherness with general learning or special learning about setting the purpose of character education methods of learning that can develop the curriculum; (2) principles and characteristics of material development at SD Muhammadiyah 12 Pamulang Tangerang Selatan that the materials applied in this school are not only using available school facilities and infrastructure but also the school environment becomes learning objects or materials applied; (3) the principles and characteristics of the lesson plan at SD Muhammadiyah 12 Pamulang Tangerang Selatan.

\section{REFERENCES}

[1] D. Lase, "Pendidikan di Era Revolusi Industri 4.0," Sundermann J. Ilm. Teol. Pendidikan, Sains, Hum. dan Kebud., vol. 1, no. 1, pp. 28-43, 2019.

[2] P. Stabback, "What Makes a Quality Curriculum? In-Progress Reflection No. 2 on" Current and Critical Issues in Curriculum and Learning".," UNESCO Int. Bur. Educ., 2016.

[3] K. Kranthi, "Curriculum Development," IOSR J.
Humanit. Soc. Sci., vol. 22, no. 02, pp. 01-05, Feb. 2017, doi: 10.9790/0837-2202030105.

[4] K. Mohanasundaram, "Curriculum Design and Development," J. Appl. Adv. Res., vol. 3, no. S1, p. 4, May 2018, doi: 10.21839/jaar.2018.v3iS1.156.

[5] F. C. Lunenburg, "Curriculum development: Inductive models," Schooling, vol. 2, no. 1, pp. $1-8,2011$.

[6] J. D. Brown, "EIL curriculum development," Princ. Pract. Teach. English as an Int. Lang., pp. 147-167, 2012.

[7] I. Nuraziz, "Curriculum Development of KKNI at English Education Department of INKAFA Gresik," JALIE; J. Appl. Linguist. Islam. Educ., vol. 1, no. 2, pp. 403-433, 2018.

[8] M. A. Khan and L. S. Law, “An Integrative Approach to Curriculum Development in Higher Education in the USA: A Theoretical Framework.," Int. Educ. Stud., vol. 8, no. 3, pp. 66-76, 2015.

[9] L. F. Luque Vega, E. Lopez Neri, A. Santoyo, J. Ruíz Duarte, and N. Farrera Vázquez, "Educational Methodology Based on Active Learning for Mechatronics Engineering Students: towards Educational Mechatronics," Comput. y Sist., vol. 23, no. 2, Jun. 2019, doi: 10.13053/cys23-2-3196.

[10] S. Nasution, Kurikulum dan Pengajaran. Jakarta: Bumi Aksara, 2010.

[11] Abdullah Idi, Pengembangan Kurikulum Teori dan Praktik. Jogjakarta: Ar-Ruzz Media, 2011.

[12] Oemar Hamalik, Dasar-dasar Pengembangan Kurikulum. Bandung: PT. Remaja Rosdakarya, 2008. 